\title{
A második gazdaság földrajza
}

Országos Tervhivatal Tervgazdasági Intézete, Budapest 1989. $172 o$.

$$
\text { Nemes Nagy József - Ruttkay Éva }
$$

Már a könyv címe is meghökkenti az olvasót, hiszen az elsô gazdaság földrajzáról sem jelent meg új, összefoglaló igényû́ irás csaknem két évtizede Magyarországon. Így valóban hiánypótló és értékes mû́ képezi ismertetésünk tárgyát.

A szerzốpáros arra tesz sikeres kísérletet, hogy a , legális magánszektor" és a lakossági kiegészitõ- és melléktevékenységek területitelepülési jellemzôit, ill. azok mứködését elemezze. Ezt - a közismert statisztikai forrás nehézségeken túllépve - logikus gondolatmenetben, érdekes alapadatokkal bizonyítva teszik.

A második gazdaság 1979 óta fokozatosan növekedố hozzájárulása a nemzeti jövedelemhez azt eredményezte, hogy a magyar gazdaság a nyolcvanas évek közepére több szektorúvá vált. Egyes tevékenységi körökben (pl. mezôgazdaság 33,9\%, lakásépítésben 60,7 $\%$, fogyasztási szolgáltatásokban $55,5 \%$, idegenforgalmi szálláskiadásban $71 \%$ ) olyan mértékũ a magánszektor és a lakossági kiegészitố tevékenység részesedése, hogy domináns módon visszahat magára az elsố szektorra, s bizonyos átfogó földrajzi jellemzôkkel bír.

A második gazdaság legsúlyosabb ágazata a mezôgazdasági kistermelés, melynek térbeli jellemzôjeként a , perifériára szorulást" mutatják be a szerzốk: az Ốrségben, a Vendvidéken, a Dráva mentén stb., tehát a legelmaradottabb aprófalvas kistérségekben a legmagasabb az arányuk. Ez elgondolkodtató, hiszen egy esetleg újjáéledố mezốgazdasági magánszektornak a fogyasztópiachoz közeli, infrastrukturálisan feltárt régiókban inkább volna esélye. A háztáji- és kisegítố gazdaságok - melyeket tájkörzetenként is bemutatnak - fôleg az Alföldhöz kötôdve, térségitelepülési kiegyenlítô szerepet játszanak.
A következố fejezetekben a ,városi" második gazdaság megyei szintũ vizsgálatáról olvashatunk. A hatféle tevékenységet (magánkereskedelem, szerzôdéses kereskedelem, szobakiadás, mellékállás, magánkisipar, kisvállalkozások) a szerzốk változatos módszerekkel, szemléletes kartogramokkal és táblázatokkal írják le, kifejezetten élvezetes stílusban: hogyan , robban be” a magántevékenység a szállításba, hogyan terjedt, majd torpant meg a szerzôdéses kereskedelem, melyek az ingatlanbérbeadásnak és a fizetôvendéglátásnak a területi problémái? A falusi turizmusról például megállapítják, illúzió azt várni, hogy a jelenlegi infrastruktúra, illetve , háttérszolgáltatások" mellett "húzóágazattá" váljon (74. oldal).

Szakmailag a legbriliánsabb fejezetnek tứnik az új típusú kisvállalkozások területitelepülési diffúziójának bemutatása. Az innovációs folyamatok Budapest kerületeibốl kiindulva a Vend vidéken alakult ,,O” számú gmkkig nyernek bemutatást és igazolást.

A kisvállalkozások belsô és térbeli múködésérổ egyedi empirikus felmérés alapján írnak a szerzốk. Igen szellemes táblázatban mutatják be a kisvállalkozók jövôképét, gazdasági erejük tükrében.

Végsố summázatként megállapítják, hogy , ,a két gazdaság jelene és jövôje szétválaszthatatlan", de hozzátehetjük: mind az elsô, mind a második szférának a valóságos vállalkozás irányában kell elmozdulnia ahhoz, hogy térségi-települési szempontból is új esélyekeı teremthessenek. Talán e rövid ismertetésbốl is kiderül, hogy a szerény kivitelũ könyvecskє gazdag ismeretanyagot hordoz, úgy ,,máso. dik gazdaság" módra, , ,elsốrangú színvonalon", amelyet szívesen ajánlok minden érdek. lődổ figyelmébe.

Csatári Bálin 